\title{
ANALYSIS OF THE FAILURE PROTECTION SYSTEM 20 KV CBO T75B SUBSTATION MALIBU FEEDER PT PLN (PERSERO) UP3 MENTENG
}

\section{Doni Abdul Mukti, Budi Sudiarto}

Engineering Faculty University of Indonesia, Depok, Indonesia

Email: donnymucktee@gmail.com,kuliahbudi@gmail.com

\begin{abstract}
Protection is a safety in the electric power system installed in the electric power distribution system, power transformer, electric power transmission, and electric generator used to secure the power system electricity from electrical disturbances or overloads by separating the disturbed parts of the electric power system from the undisturbed electrical power system so that the undisturbed electrical system can continue to work. The protection system at the T75B substation has a work failure where when there is a short circuit on the consumer side, it causes the PMT (Power Breaker) for the Malibu Feeder at the Kebon Sirih Substation to trip while the CBO (Circuit Breaker Outgoing) cubicle at the T75B substation does not trip. This resulted in an unexpected widespread blackout. To find out the cause of the failure of the protection system, several tests and analyzes were carried out, namely protection design testing, protection relay coordination testing, protection system construction analysis, protection equipment performance testing. It is hoped that the test results can be used as a reference for improvement so that similar failures do not recur.
\end{abstract}

Keywords: protection system; short circuit; PMT; CBO

Received: 2021-10-20; Accepted: 2021-11-05; Published: 2021-11-20

\section{Introduction}

Protection is electrical safety in the electric power system installed in the electric power distribution system, power transformer, electric power transmission and electric generator used to secure the electric power system from electrical disturbances or overload, by separating the disturbed part of the electric power system from the undisturbed electric power system so that the uninterrupted electrical system can continue to work (flow current to the load). A protection system consisting of one or more protective equipment, measuring transformer, wiring, tripping circuit, power supply and communication system if available. Arrangement of one or more protective equipment and other equipment intended to perform one or more specific protective functions. Basic election protection of electric power is as follows:

1. Reduced damage to the equipment that was disturbed and equipment adjacent to the point of interruption

2. Reduces problems extends

$\begin{array}{ll}\text { How to cite: } & \text { Mukti. D. A. \& Sudiarto. B (2021) Analysis of The Failure Protection System 20 KV CBO T75B } \\ & \text { Substation Malibu Feeder PT PLN (Persero) UP3 Menteng, } 6 \text { (2), Syntax Literate: Jurnal Ilmiah Indonesia } \\ \text { E-ISSN: } & 2548-1398 \\ \text { Published by: } & \text { Ridwan Institute }\end{array}$


3. to Minimize the duration of the disruption

4. Minimize danger to humans

5. Maximizing the availability of electricity to the consumer

Protection contained in the substation T75B serves to secure intrusion coming from installation customers. However, on June 6, 2021, at 00.12 WIB, disturbances arising from the customer installation in the form of a 3-phase short circuit of 8,500 A did not activate the protection at the T75B Substation properly so that the Malibu Feeder PMT (Power Breaker) tripped and This resulted in blackouts of all Malibu Feeders which should not have occurred. From the technical side, the widespread blackout reduced the reliability of the distribution network of PT. PLN (PERSERO). Meanwhile, from an economic point of view, this is detrimental to PT. PLN (PERSERO) because it cannot sell electrical energy in areas that are not experiencing disturbances. In addition, widespread blackouts also give a bad image in the eyes of the public.

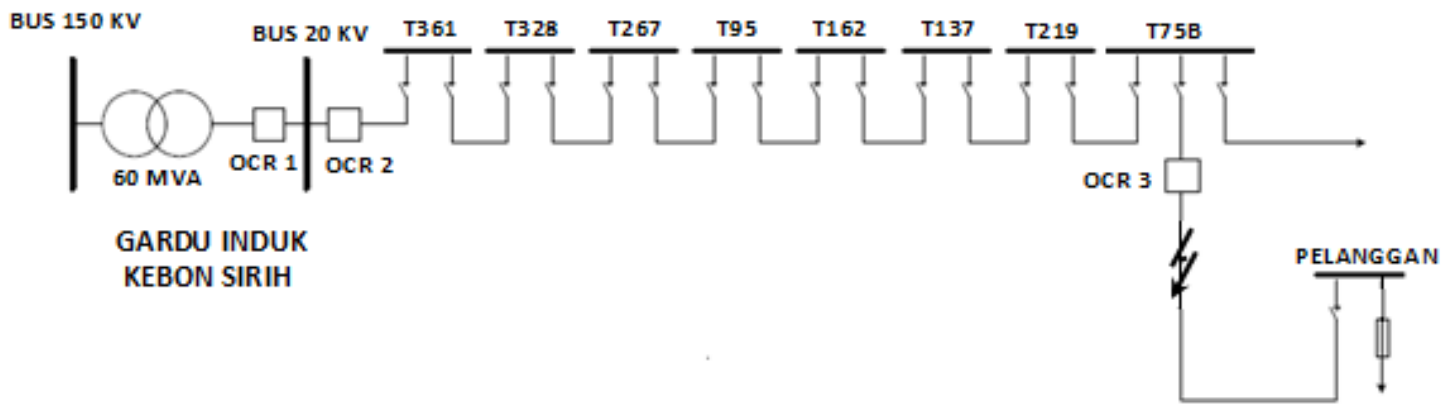

Figure 1

\section{Short Circuit Position}

Therefore, the author chose the title "Analysis of the Failure Protection System 20 KV CBO T75B Substation Malibu Feeder PT PLN (Persero) UP3 Menteng" to find the cause of the failure and follow-up repairs. It is hoped that with this analysis, similar incidents can be avoided to reduce potential losses and increase the reliability of PT PLN (Persero) UP3 Menteng.

\section{Methods}

\section{Calculation of CT Saturation at the T75B Substation}

The CT data installed at the T75B Substation is as follows:

Type : TCI-24-2B

Nominal Frequency : $50 \mathrm{~Hz}$

CT Ratio : :75/5 A

Protection Class $\quad: 5 \mathrm{P} 15$ 
The installed CT protection coil has a protection class of 5P15. Following IEC number 60044-1 (2003): Instrument Transformers, Part 1: Current Transformers [ETD 34: Instrument Transformers] and SPLN number 76 of 1987 concerning Current Transformers, protection class 5P15 means the CT has a composite error of 5\% when current is applied. 15 times the nominal current. This measurement class indicates the saturation point of the protective CT. Means CT will saturate at $75 \mathrm{~A} \times 15=1125 \mathrm{~A}$

\section{Relay Coordination Testing Relay}

Coordination testing using FSC Curve software with the following steps the parameters used (CT ratio, current setting, TMS, SIT (Standard Inverse Time) or DT (Definite Time) curve, short circuit current, voltage) with IEC standards.

Table 2

\begin{tabular}{|c|c|c|c|c|c|c|c|c|c|}
\hline \multirow[b]{2}{*}{ No } & \multirow{2}{*}{$\begin{array}{l}\text { Relay } \\
\text { Position }\end{array}$} & \multicolumn{2}{|c|}{$\mathrm{OC}(\mathrm{NI})$} & \multicolumn{2}{|c|}{$\begin{array}{l}\text { MOC } \\
(\mathrm{DT})\end{array}$} & \multicolumn{2}{|c|}{ GF (NI) } & \multicolumn{2}{|c|}{ MGF (DT) } \\
\hline & & $\begin{array}{l}\text { Iset } \\
\text { (A) }\end{array}$ & $\begin{array}{c}\mathrm{TM} \\
\mathrm{S}\end{array}$ & $\begin{array}{l}\text { Iset } \\
\text { (A) }\end{array}$ & $\begin{array}{c}\mathrm{Td}( \\
\mathrm{s})\end{array}$ & $\begin{array}{l}\text { Iset } \\
\text { (A) }\end{array}$ & $\begin{array}{c}\mathrm{TM} \\
\mathrm{S}\end{array}$ & $\begin{array}{l}\text { Iset } \\
( \\
\text { A) }\end{array}$ & $\begin{array}{c}\mathrm{Td}(\mathrm{s} \\
)\end{array}$ \\
\hline 1 & $\begin{array}{c}\text { Substatio } \\
\mathrm{n} \\
\mathrm{T} 75 \mathrm{~B} \\
\end{array}$ & 127.5 & 0.05 & $\begin{array}{c}637 . \\
5\end{array}$ & 0 & 31.5 & 0.05 & 159 & 0 \\
\hline 2 & $\begin{array}{c}\text { PMT } \\
\text { P. } \\
\text { Malibu }\end{array}$ & 320 & 0.15 & 4400 & 0.2 & 120 & 0.12 & 880 & 0.2 \\
\hline
\end{tabular}

Then Plotting The curve will display the results of the relay coordination curve as follows.

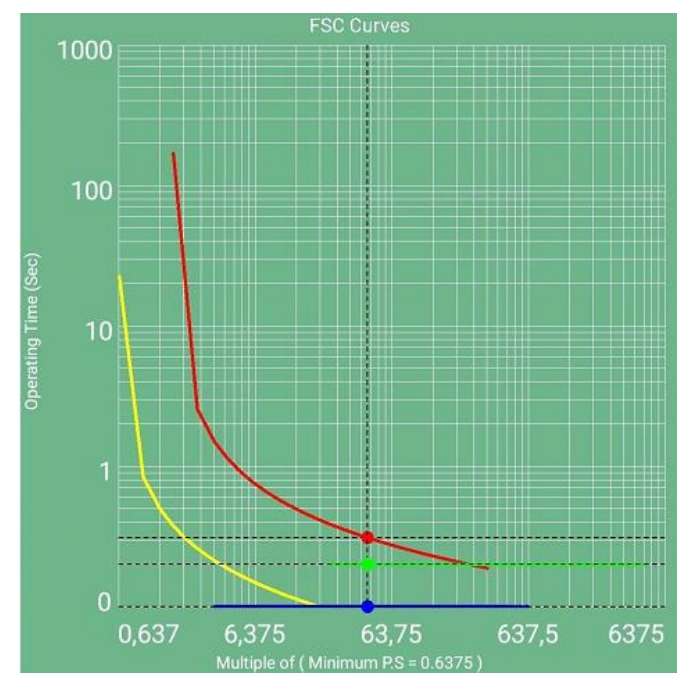

Figure 2.

Display of SIT and DT Curves When Over Current on the FSC Curve

Description :

Yellow Line $\quad$ : Over Current, SIT (CBO T75B) 
Red Line

Blue Line

GreenLine
: Over Current, SIT (PMT MALIBU)

: Over Current Moment, DT (CBO T75B)

: Over Current Moment, DT (PMT MALIBU)

\section{Construction Analysis of Protection System Components}

Checking the wiring connections between current transformers, voltage transformers, protection relays, and mechanical circuit breakers as shown below :

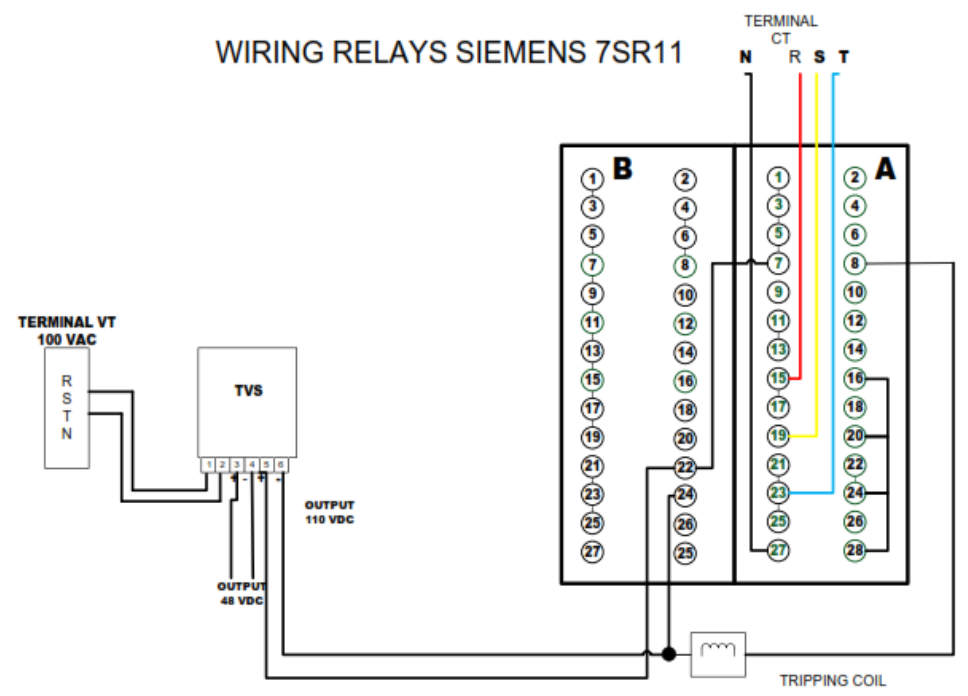

Figure 3

Connection of Protection Components

\section{Performance Testing of Protection Equipment}

1) The CT Ratio

The CT Ratio is carried out to determine the ability of CT to transform current from the primary side to secondary side. The CT ratio test is carried out using a tool single phase relay test set brand SVERKER 760. Primary current and secondary current are compared to determine the percentage of CT error. The results of the CT ratio test installed at the T75B Substation are as follows:

Table 3

Test Results of R Phase CT Ratio with CT Ratio 75/5 A

\begin{tabular}{cccc}
\hline Primary & Secondary & Ip/Is & Accuracy \\
\hline 25 & 1.7 & 14.7058824 & 0.98039216 \\
\hline 50 & 3.4 & 14,7058824 & 0.98039216 \\
\hline 75 & 5 & 15 & 1 \\
\hline 100 & 6,7 & 14,9253731 & 0,99502488 \\
\hline 125 & 8,5 & 14,7058824 & 0,98039216 \\
\hline
\end{tabular}

Table 4

Test Results for S Phase CT Ratio with CT Ratio 75/5 A 


\begin{tabular}{cccc}
\hline Primary & Secondary & Ip/Is & Accuracy \\
\hline 25 & 1.7 & 14,7058824 & 0.98039216 \\
\hline 50 & 3.35 & 14,9253731 & 0.99502488 \\
\hline 75 & 5.02 & 14.940239 & 0.99601594 \\
\hline 100 & 6.74 & 14.8367953 & 0.98911968 \\
\hline 125 & 8.43 & 14.8279953 & 0.98853302 \\
\hline
\end{tabular}

Table 5

Test Result of T Phase CT Ratio with CT Ratio 75/5 A

\begin{tabular}{cccc}
\hline Primary & Secondary & Ip/Is & Accuracy \\
\hline 25 & 1.68 & 14.8809524 & 0.99206349 \\
\hline 50 & 3.35 & 14.9253731 & 0.99502488 \\
\hline 75 & 5.02 & 14.940239 & 0.99601594 \\
\hline & & & \\
\hline & & 1006.74 \\
& & & 14.8367953 \\
& & & 0.98911968 \\
& & & 1258.43 \\
& & & 0.98853302 \\
\hline
\end{tabular}

2) Relay Function Testing and PMT

Testing protection system functions are performed using a single-phase relay test set for the brand SMC type PTE-100-C. The method of testing the function of the protection system is to connect the CT, relay, and mechanical circuit breaker system, then flow several times the current setting of the relay on the secondary side of the CT and record the time it takes for the circuit breaker to trip.

Table 6

\begin{tabular}{clccc}
\hline No & Relay & Primary & I test $(\mathbf{A})$ & Time $(\mathbf{s})$ \\
\hline 1 & OC & 127.5 & 130 & 0.35 \\
\hline 2 & OC $(\mathrm{Hi})$ & 637.5 & 650 & 0.23 \\
\hline 3 & GF & 31.5 & 35 & 0.41 \\
\hline 4 & GF $(\mathrm{Hi})$ & 159 & 165 & 0.25 \\
\hline
\end{tabular}

\section{Results and Discussion}

In the design error testing process, the results of the CT calculation have a saturation current of 1.125 Ampere so that it will be saturated (saturated) when a shortcircuit fault current is flowed by 8,500 Ampere. This saturation means that the CT is not able to transform the current beyond its capacity. In testing the relay coordination using the FSC software, it was Curve found that the comparison of the Over Current (OC) curve with the IEC-NI standard between the CBO substation T75B and the PMT GI Feeder Malibu did not cross/touch. Likewise, the comparison of the Moment Over 
Current (MOC) curve with the IEC-DT standard does not touch/cross. This indicates that the protection coordination between the T75B substation $\mathrm{CBO}$ and the Malibu Substation GI PMT is good. Testing for construction errors showed that the components of the protection system were properly connected to the terminals. Equipment error testing shows that the ratio of the current transformer has an accuracy above 98 percent, while the relay and PMT functions can work well. So, through the overall analysis carried out, it was found that the cause of the protection failure was the saturation of the Current Transformer at the CBO substation T75B.

\section{Conclusion}

Based on the analysis of the case of failure of the protection system at the substation $\mathrm{T} 75 \mathrm{~B}$, it was concluded that the CT CBO substation $\mathrm{T} 75 \mathrm{~B}$ has a saturation level of 1,125 Ampere so that when it is fed short-circuit fault current of 8500 Ampere, $\mathrm{CT}$ is experiencing saturation so it cannot trigger the relay to work. This resulted in PMT CBO Substation T75B not trip. 


\section{BIBLIOGRAFI}

Argo Dahono, Scream. 2011. Voltage Imbalance and Its Effects. Taken from:https://konversi.wordpress.com/2011/04/15/imbalance-voltage and- its influence/

Kadarisman, Pribadi. 2014. Short Circuit Calculation and OCR Coordination. Jakarta: Workshop on Distribution Network Security.

Sarimun N., Wahyudi. 2016. Protection of Electric Power Distribution System. Depok : Garamond

Single Line Diagram 20 kV UP3 Menteng. 2019. Jakarta: PT. PLN (Persero) Main Distribution Unit for Greater Jakarta UP3 Menteng

SPLN 76: 1987, Current Transformer. 1987. Jakarta: Ministry of Mines and Energy, State Electricity Company.

SPLN 64: 1995, Impedance of Conductor Wire. 1995. Jakarta: Ministry of Mines and Energy, State Electricity Company.

Wirawan, 2013. Basic Out Of Step Relay Protection and Tuning Systems on Synchronous Generators. Jakarta: PLN Research Institute

\section{Copyright holder:}

Doni Abdul Mukti, Budi Sudiarto (2021)

First publication right:

Syntax Literate: Jurnal Ilmiah Indonesia

This article is licensed under:

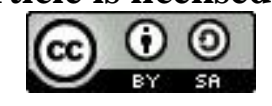

